\title{
НАПРЯМИ РЕФОРМУВАННЯ ПОДАТКУ НА ДОХОДИ ФІЗИЧНИХ ОСІБ
}

\section{DIRECTIONS OF INCOME TAX REFORM INDIVIDUALS}

\author{
Данилишин Володимир Іванович \\ кандидат економічних наук, доцент, \\ Івано-Франківський навчально-науковий інститут менеджменту \\ Західноукраїнського національного університету \\ ORCID: https://orcid.org/0000-0003-2923-0806 \\ Синиця Світлана Михайлівна \\ кандидат економічних наук, доцент, \\ Івано-Франківський навчально-науковий інститут менеджменту \\ Західноукраїнського національного університету \\ ORCID: https://orcid.org/0000-0003-4791-7548
}

\author{
Danylyshyn Volodymyr, Synytsia Svitlana \\ Ivano-Frankivsk Educative and Research Institute \\ of Management of West Ukrainian National University
}

\begin{abstract}
Стаття присвячена актуальним питанням щодо оподаткування доходів фрізичних осіб. Сьогодні національна система оподаткування не зовсім справляється із виконанням покладених на неї фрункцій стосовно здійснення загального оподаткування, фріскальної достатності та соціальної справедливості, рівності платників податків та прозорості процедур адміністрування. Саме тому проаналізовано досвід ряду економічно розвинутих держав стосовно оподаткування доходів громадян. Окреслено найкращі розробки іноземних систем оподаткування доходів та вказані кроки, які дадуть змогу удосконалити та модернізувати систему оподаткування доходів громадян в Україні. Запропоновано реформувати систему оподаткування таким чином, щоб обкладати податком на доходи фрізичних осіб не персонально кожного українця, який працює, а відразу ціле домогосподарство або сім'ю.
\end{abstract}

Ключові слова: податок на доходи фрізичних осіб, зарубіжний досвід оподаткування, прогресивна шкала оподаткування, ставка податку, податкова реформа.

Статья посвящена актуальным вопросам относительно налогообложения доходов фризических лиц. Сегодня национальная система налогообложения не совсем справляется с выполнением возложенных на нее функций по осуществлению общего налогообложения, фрискальной достаточности и социальной справедливости, равенства налогоплательщиков и прозрачности процедур администрирования. Именно поэтому проанализирован опыт ряда экономически развитых государств по налогообложению доходов граждан. Определены лучшие разработки иностранных систем налогообложения доходов и указаны шаги, которые позволят усовершенствовать и модернизировать систему налогообложения доходов граждан в Украине. Предложено реформировать систему налогообложения таким образом, чтобы облагать налогом на доходы фризических лиц не персонально каждого украинца, который работает, а сразу целое домохозяйство или семью.

Ключевые слова: налог на доходы фризических лиц, иностранный опыт налогообложения, прогрессивная шкала налогообложения, ставка налога, налоговая реформа.

The article is devoted to topical issues related to personal income taxation. Today, the national tax system does not quite cope with the functions entrusted to it in relation to the implementation of general taxation, fiscal sufficiency and social justice, equality of taxpayers and transparency of administrative procedures. In the conditions of unstable economic situation in the state, rather high level of shadowing of economy, use of mechanisms of tax evasion, essential stratification of incomes of the population there is an urgent need of improvement and modernization of tax and financial policy of the state. That is why the experience of a number of economically developed countries regarding the taxation of citizens' incomes is analyzed. The best developments of foreign systems of income taxation are outlined and the steps that will allow to improve and modernize the system of income taxation of citizens in Ukraine are indicated. It is proposed to reform the taxation system in such a way as to tax the personal income tax 
not individually of each Ukrainian who works, but at once the whole household or family. As a result of the proposed reform, our citizens will receive more money by refunding part of the tax, and ultimately it will be possible to reduce the payment of subsidies and various social benefits. At the same time, social protection services will be able to focus on helping those citizens who really need it, ie people with disabilities and large families.Such innovations will also encourage Ukrainians not to hide their income, because they will know that part of the tax paid will be refunded by the end of the year. The current system in our country leads to discrimination, because, for example, a working citizen whose family has minor children or disabled people, in fact assumes part of the functions of the state to maintain them, but pays taxes as much as who is not forced to take care of anyone, which is why it is wrong to take taxes from such working citizens. However, before implementing this reform in practice, it is necessary to make a number of changes, namely to calculate the current real subsistence level, which is clearly higher than that set today, it will be necessary to gradually increase the welfare of the population to the real subsistence level. for each family member, calculate the percentage of taxation so that after paying taxes the income for each family member does not fall below the subsistence level.

Keywords: personal income tax, foreign experience of taxation, progressive tax scale, tax rate, tax reform.

Постановка проблеми. Питання оподаткування доходів традиційно посідає доволі важливе місце у наукових дискусіях як в Україні, так і у світі, оскільки тісно пов'язано із ростом добробуту громадян, створенням стимулів до отримання освіти, підвищення професійних вмінь та навичок. Історично податки на доходи були і залишаються одним із вагомих джерел формування державного і місцевих бюджетів. Їх запровадження в країнах Америки та Європи багато років тому було спричинено зростанням фріскальних потреб держав.

Оподаткування доходів позначається на рівні конкурентоспроможності податкової системи, впливаючи на потоки й обсяги капіталу, трудових ресурсів, що фрормують важливі передумови для економічного зростання в країні.

В умовах нестабільної економічної ситуації в державі, досить високого рівня тінізації економіки, використання механізмів ухилення від сплати податків, суттєвого розшарування доходів населення назріла нагальна потреба удосконалення та модернізації податкової та фрінансової політики держави. У зв'язку 3 вибраним курсом України щодо інтеграції до Європейського союзу та створення соціально орієнтованої ринкової економіки гостро постає питання пошуку шляхів удосконалення національної системи оподаткування доходів фрізичних осіб із використанням світового досвіду у даній сорері.

Аналіз останніх досліджень і публікацій. Теоретичні засади оподаткування розроблені в працях багатьох видатних учених, таких як: Д. Кейнс, Д. Рікардо, А. Сміт, А. Вагнер, Д. Міль, А. Лафрфер. Проблеми реалізації податкової політики України щодо ефективного формування бюджетів, удосконалення механізму прибуткового оподаткування громадян висвітлювали також і вітчизняні науковці, серед яких: В. Андрушко, В. Вишневський, Ю. Іванов, М. Кучеренко, В. Мельник,
В. Опарін, В. Федосов, К. Швабій. Порівняння механізму оподаткування фрізичних осіб в Україні та в інших країнах, а також визначення напрямів здійснення податкової реформи проводилися такими вченими, як: В. Андрущенко, О. Василик, В. Федосов, Д. Черник, І. Якущик та інші. Проблемним питанням оподаткування доходів фрізичних осіб також присвячені праці таких українських учених, як: Т. Даценко, О. Десятнюк, П. Лайк, О. Кириленко, О. Кобилянська, А. Соколовська, І. Чугунова, С. Юрій.

Постановка завдання. Метою статті $\epsilon$ визначення особливостей справляння та адміністрування прибуткового податку в країнах $Є С$ та США та розроблення рекомендацій щодо ресрормування механізму оподаткування доходів громадян України.

Виклад основного матеріалу дослідження. Кожна держава вибирає свої власні методичні підходи з метою здійснення оподаткування доходів фрізичних осіб, однак визначальною ознакою такого оподаткування $\epsilon$ те, що воно повинне сприяти збільшенню заощаджень населення держави, які в майбутньому слугуватимуть одним із джерел для срінансування економіки країни. Кожна держава будує свою індивідуальну систему оподаткування доходів населення.

Інтеграція у європейське співтовариство, а також побудова соціально-орієнтованої економіки $є$ стратегічною метою України, відповідно вдосконалення та реформування національної системи оподаткування має виходити саме з цієї мети. Така система повинна бути гармонізованою із податковими системами інших розвинутих зарубіжних держав. Проте на даний час в системі адміністрування податку на доходи фрізичних осіб (ПДФО) в Україні є певні дисбаланси та проблеми, серед яких ми можемо виділити наступні [15, с. 773]:

- неврахування досвіду розвинутих зарубіжних держав під час справляння ПДФО; 
- певні прогалини в законодавстві у частині призначення податкової соціальної пільги;

- відсутність прогресивної шкали оподаткування доходів фрізичних осіб;

- доволі низький рівень податкової культури і фрінансової грамотності населення держави; жаві;

- присутній суттєвий рівень корупції в дер-

- значне використання незаконних і «напівзаконних» механізмів ухилення від сплати ПДФО;

- неефективна робота щодо запровадження мір по легалізації доходів громадян, які перебувають у тіньовому секторі економіки.

У економічно розвинених країнах західної Європи, а також північної Америки податок на доходи фрізичних осіб $є$ основним фріскальним податком, де вагомий фріскальний тягар несуть саме заможні громадяни. Бідне населення або цілком не сплачує індивідуальний податок, або ж сплачує його невелику частку від отриманого доходу, що є прикладом ефективного застосування принципу соціальної справедливості податкових систем. Це зумовлено специфрікою західної податкової політики. Однією із основних функцій системи державних фрінансів держав Європейського Союзу є забезпечення високих соцстандартів життя громадян. Для формування системи державних фрінансів у більшості європейських держав видатки на соціальне страхування та соціальні трансфрерти фрінансуються лише від поступлень податку на доходи фрізичних осіб. Саме така модель, на нашу думку, $\epsilon$ економічно раціональною та соціально справедливою [11, с. 18].

Досконалої податкової системи не існує в жодній державі світу. Проте доцільно проаналізувати і розглянути позитивний досвід деяких з них. Економічно розвинуті держави охарактеризовуються не тільки доволі високим рівнем доходів населення, але і високими ставками податків. Головна перевага і особливість податкових систем зарубіжних країн $€$ оподаткування за прогресивною шкалою, тобто водночас із збільшенням доходу росте ставка податку. В таблиці 1 представлені максимальні ставки оподаткування доходів громадян у різних країнах світу.

У Франції фрункції адміністрування ПДФО виконує податкова служба. У відповідності до податкової системи Франції всі доходи населення поділяються на вісім груп, зокрема: сільськогосподарські доходи; доходи від здачі в оренду будівель і земель; оплата за роботу по найму; доходи від оборотного капіталу
Таблиця 1

Максимальні ставки ПдФо у зарубіжних країнах [1; 15]

\begin{tabular}{|l|c|}
\hline \multicolumn{1}{|c|}{ Країни } & Ставки, \% \\
\hline Франція & 45 \\
\hline Швеція & 57 \\
\hline Данія & 52 \\
\hline Іспанія & 52 \\
\hline Бельгія & 54 \\
\hline Португалія & 48 \\
\hline Великобританія & 45 \\
\hline Іспанія & 45 \\
\hline Німеччина & 45 \\
\hline Норвегія & 39 \\
\hline Італія & 43 \\
\hline США & 37 \\
\hline
\end{tabular}

(дивіденди та проценти); доходи від промислової та торгівельної діяльності фрірм, які не $€$ акціонерними товариствами; некомерційні доходи (тобто доходи осіб вільних професій), по кожній з яких існує своя специфріка розрахунку, а також використовуються пільги та відрахування. Податок обчислюється не на окремого громадянина, а на родину загалом за прогресивною шкалою від 14\% до 45\%. Максимальну ставку використовують щодо доходу родини розміром понад 156244 євро, а неоподатковуваний мінімум становить 6011 євро в рік [15, с. 775].

У Німеччині діє аналогічна фрранцузькій система оподаткування. ПДФО вважається одним із бюджетоутворюючих у Німеччині. Під час стягування податку беруть до уваги податкові класи і види діяльності, а також застосовують податкові карти та таблиці. Загалом існує 6 податкових класів, які розділяють платників в залежності від їхнього сімейного стану, від кількості працюючих у родині, від наявності дітей, а також від окремого або спільного ведення бюджету родини. Шкала ставок податку дифреренціюється від 14\% до 45\%. Доходи, розмір яких менший, ніж 9169 євро на рік оподатковуються за ставкою $0 \%[15$, c. 772$]$.

Протягом тривалого часу у Великобританії існувала шедулярна срорма оподаткування доходів громадян, що означала диференціацію оподатковуваних доходів за певною ознакою, яка вважається найбільш справедливою у сучасному світі. Виділяли 6 груп шедул: A, B, C, D, E, F, але після ресрорми 2005 року, всі групи були об'єднані, а групи А (доходи від власності і орендованого майна) та D (доходи 
від комерційно-виробничої діяльності) залишаються актуальними і досі [10]. Неоподатковуваний мінімум (ставка 0\%) використовується до річного доходу, який не перевищує 12500 фрунтів стерлінгів, а загалом податкові ставки є 20\%, 40\%, 45\% [15, с. 771].

В Італії податок на доходи фрізичних осіб сплачують як приватні особи-резиденти, так і нерезиденти. Причому оподатковуються усі доходи резидентів, ті, які отримані на митній території держави та за її межами, а нерезидентів - тільки доходи, які отримані на митній території Італії.

Усі доходи платників податку диференціюються на 5 груп, які залежать від джерел їх надходжень. До 1 групи входять доходи, які отримані від нерухомості, зокрема будівель, земельних ділянок, а також ведення особистої сільськогосподарської діяльності. У 2 групу входять доходи від різноманітних видів грошової ренти (відсотки за поточними і депозитними банківськими рахунками, позиками, за облігаціями та іншими цінними паперами). У третій групі об'єднано усі трудові доходи, в тому числі і доходи осіб вільних професій. У 4 групу включаються доходи від приватних комерційних фрірм. П'ята група містить в собі прибуток від спекулятивного перепродажу нерухомого майна, землі, предметів мистецтва тощо. Доходи кожної 3 перелічених груп оподатковуються окремо, за ставками від 23\% до 43\% [12, с. 266].

В Канаді існує особистий прибутковий податок, який сплачується як на федеративному, так і на провінційному рівнях. На фредеративному рівні не оподатковуються доходи нижчі 10382 доларів в рік, до інших доходів застосовуються 4 ставки:

$-15 \%-10382 \$-41544 \$$;

$-22 \%-41545 \$-83088$;

$-26 \%-83$ 089\$-128 800\$;

- 29\% (максимальна ставка) - 128 801\$ і вище.

Таблиця 2

Шкала ставок податку на доходи фрізичних осіб (для платників, які подають індивідуальну декларацію)

\begin{tabular}{|c|c|}
\hline Ставка & Річний дохід, дол. США \\
\hline $10 \%$ & $0-9525$ \\
\hline $12 \%$ & $9526-38700$ \\
\hline $22 \%$ & $38701-82500$ \\
\hline $24 \%$ & $82501-157500$ \\
\hline $32 \%$ & $157501-200000$ \\
\hline $35 \%$ & $200001-500000$ \\
\hline $37 \%$ & понад 500001 \\
\hline
\end{tabular}

На провінційному рівні застосовуються ставки у розмірі 7-21\%.

В США ставки особистого прибуткового податку поділяються на сім рівнів, а також диференціюються від сімейного статусу особи. Зокрема розрізняють наступні ставки податку у США - це 10, 12, 22, 24, 32, 35 та 37\%. Сімейні статуси можуть бути: одна особа; подружжя із спільним декларуванням доходів, а також вдова, вдівець; подружжя з окремим декларуванням доходів; голова домогосподарства.

Відповідно до податкового законодавства США найменшу ставку податку буде сплачувати одна особа у розмірі 10\%, при умови, що ії дохід не більший 9525 доларів США на рік, а для подружжя зі спільним декларуванням доходів дана сума збільшується у два рази [10]. Найвища ставка 37\% використовується щодо доходу однієї особи у розмірі, який перевищує $500001 \$$ у рік [15, с. 773].

У США фрункціонує два види вирахувань 3 суми оподатковуваного доходу фрізичних осіб - постатейні та стандартне. Але платник податку має право обрати лише один вид вирахувань: або у вигляді певної фріксованої суми (тобто стандартне вирахування), або в залежності від розміру дозволених до вирахувань витрат, при умові, що такі витрати були понесені платником (тобто постатейні вирахування). На вибір платника між переліченими двома видами вирахувань впливає те, наскільки перший чи другий із них дозволить зменшити його оподатковуваний дохід і, відповідно, зменшити розмір нарахованих йому податкових зобов'язань. Інший аргумент полягає в тому, що для оформлення постатейних вирахувань платник податків повинен не тільки заповнити певні додаткові фрорми (зокрема, Додаток А форми 1040), але і здійснювати облік, а також подати документи, які будуть підтверджувати відповідні здійснені витрати. Усе це робить процес отримання постатейних вирахувань доволі складнішим у порівнянні із стандартними вирахуваннями.

Для стандартного вирахування існує фріксована сума у розмірі 12000 дол. США для індивідуальних платників та 24000 дол. США для платників, які одружені та подають спільну декларацію.

Що стосується постатейних вирахувань, то раніше їхній рівень був обмежений або 3\% від скоригованого валового доходу (adjusted gross income) фрізичної особи, або 80\% загальної суми постатейних витрат (при цьому обиралась та ознака, згідно з якою отримане значення виявлялося меншим). Але у 2018 році 
такі обмеження були скасовані. В той же час суттєво зменшився склад витрат, які дозволені до вирахування. Для прикладу, у 2017 році їх перелік включав наступні витрати:

- податки на нерухоме майно, інші місцеві та регіональні податки, які сплачені платником;

- збитки завдані у результаті крадіжки чи нещасного випадку;

- медичні витрати, які не були покриті медичною страхівкою;

- благодійні внески у певні встановлені організації, але за винятком внесків до будьяких політичних партій чи пожертвувань нужденним на вулиці;

- проценти за іпотечним кредитом;

- витрати, які пов'язані із профресійною діяльністю особи, в тому числі витрати на відрядження, що не були відшкодовані працедавцем, використання власного нерухомого майна або авто для службових цілей, витрати на переїзд в інше житло, що обумовлено службовими цілями; витрати на особисте навчання, яке пов'язане із підвищенням свого кваліфікаційного рівня та інше.

Під час податкової реформи за президенства Д. Трампа деякий перелік постатейних вирахувань було скасовано, а саме: витрати на переїзд у інше житло та збитки завдані у результаті крадіжки або нещасного випадку. Величина інших витрат, на які можна зменшувати оподатковуваний дохід, було значно скорочено. Для прикладу, максимальна величина іпотечного кредиту, проценти за яким дозволено вираховувати, зменшились $31 \mathrm{mлн.} \mathrm{дол.}$ США у 2017 році до 750 тис. дол. США у 2018 році. Усі інші проценти, які нараховуються на кредит понад зазначеної суми, взагалі не підпадають вирахуванню з оподатковуваного доходу такої фрізичної особи. Максимальний розмір дозволених до вирахування із оподатковуваного доходу сплачених зобов'язань за податком на нерухоме майно, а також за усіма іншими регіональними та місцевими податками встановлена в розмірі 10 тис. дол. США.

Зрозуміло, що такі зміни мають на меті, перш за все, переорієнтувати платників податків із постатейних вирахувань 3 доходів на стандартні. Відповідно до думки економічних експертів приблизно 94\% всіх платників податків виберуть стандартне вирахування.

Податок на спадщину. Навіть незважаючи на те, що розмір податку на спадщину залишився на рівні 40\%, податкові зміни зачепили і спадкоємців. Будучи ще кандидатом у президенти США, Д. Трамп анонсував, що жодна сім'я не повинна сплачувати податок «на смерть», тому що це породжує подвійне оподаткування [13]. Як наслідок, Законом про зменшення податків та створення нових робочих місць на період з 2018 по 2025 рр. у два рази збільшено розмір суми спадщини, яка звільняється від оподаткування [2]. Незалежно від ступеня спорідненості для індивідуальних платників податків цей розмір встановлено на рівні 11,2 млн. дол. США (для порівняння у попередні роки було 5,6 млн. дол. США), а для подружжя, яке подає спільну декларацію, - на рівні 22,4 млн. дол. США (порівняно, відповідно, з 11,2 млн. дол. США).

Зарубіжні системи справляння прямого податку з доходів фрізичних осіб мають доволі перевірену часом практику становлення та розвитку на основі глибокого усвідомлення кожним громадянином - платником податку свого конституційного обов'язку - сплати податків. Суттєві соціальні видатки, а також постійна увага держави до платника податків поступово сфрормували свою індивідуальну податкову культуру, яка значно відрізняється від наших вітчизняних реалій. Крім того, зовсім по іншому розуміється і сутність такої категорії як «податок»: зокрема, в Німеччині - це підтримка, яку громадяни надають своїй державі; у Великобританії - це повинність перед державою; у США податок розуміється як «такса»; у Франції - як обов'язкова плата. Для нашої країни, як це не прикро, розуміння такої фрінансової категорії зводиться лише до примусового платежу [2; 5].

Попри те, що наша влада намагається 3 року в рік покращувати та ресрормувати систему оподаткування доходів громадян, вона все ж таки, на нашу суб'єктивну думку, залишається недосконалою та має резерви для підвищення її ефрективності. Для того, аби збільшити податкові надходження до бюджетів усіх рівнів та покращити економічну ситуацію в державі, важливо запровадити зміни щодо зменшення податкового навантаження для малозабезпечених громадян, здійснювати диореренціацію ставок податку на доходи фрізичних осіб та єдиного податку залежно від виду діяльності та розміру доходу, а також із врахуванням сімейного стану платників, кількості зайнятих у сім'ї та кількості дітей чи пенсіонерів.

Для забезпечення соціального захисту громадян, легалізації заробітної плати й боротьби 3 «тіньовим сектором економіки», поліпшення умов ведення бізнесу доцільний перегляд шкали прогресивного ПДФО у частині збільшення кількості щаблів цієї шкали, залежно від розміру річного оподатковуваного доходу, зменшення діючої ставки соціального внеску, 
а також впровадження заходів, спрямованих на виявлення платників податків, які здійснюють виплату заробітної плати «у конвертах».

Підсумовуючи, важливо розуміти, що нам не варто просто копіювати провідний світовий досвід і запроваджувати його в Україні, необхідно використати найкращі розробки іноземних систем оподаткування доходів, пристосовувати їх до українських реалій, та розробляти свою власну справедливу, ефективну, соціально спрямовану модель системи оподаткування доходів фрізичних осіб. Першочерговими напрямами подальшої податкової реформи мають стати запровадження неоподатковуваного мінімуму замість існуючої податкової соціальної пільги, а також впровадження прогресивної шкали оподаткування. Такі кроки дадуть змогу вирішити одну з головних соціально-економічних проблем України - це нерівномірність розподілу доходів між багатими і бідними. Крім того, доцільним вважаємо також запровадження окремого оподаткування доходів домогосподарств та обов'язкове впровадження податку на розкіш. Удосконалення та модернізації також потребує робота податкових органів, зокрема в частині здійснення нагляду за своєчасністю та повнотою сплати податків з доходів та унеможливити спроби ухиляння від їх сплати.

У Верховній Раді України розробляється суттєва реформа в податковій сорері. Вона передбачає, що багатьом українцям залишать більшу суму коштів, які йшли на сплату податку, але замість цього зменшать соціальну допомогу та субсидії.

Зокрема, голова комітету Верховної Ради України 3 питань соціальної політики та захисту прав ветеранів Галина Третьякова вже запропонувала змінити систему оподаткування таким чином, щоб обкладати ПДФО не персонально кожного громадянина, який працює, а відразу ж ціле домогосподарство або родину. Як ми вже зазначили вище, така система оподаткування фрункціонує в багатьох розвинутих країнах світу і вельми успішно.

Згідно слів політика, в законопроекті, який на даний момент перебуває тільки на стадії розробки, сплата ПДФО залишиться, але держава за підсумками податкового року буде повертати деяку частину податків тим домогосподарствам, доходи яких (у розрахунку на кожного члена родини) не дотягують до прожиткового мінімуму. Завдання полягає саме в тому, щоб створити нову систему оподаткування безпосередньо родини і повернути їй ПДФО, який сплатив годувальник. Таким чином годуваль- ник буде спроможний забезпечити собівартість проживання людей в родині. У результаті запропонованої ресрорми наші громадяни отримуватимуть «на руки» більшу суму грошей завдяки поверненню частини податку і в кінцевому підсумку можна буде зменшити виплати субсидій і різноманітної соціальної допомоги й не «ганяти ці гроші по колу». При цьому служби, які виконують фрункції соціального захисту, зможуть зосередитися на допомозі тим громадянам, хто цього реально потребує, тобто людям з інвалідністю та багатодітним сім'ям.

$\mathrm{Ha}$ даний час близько $40 \%$ домогосподарств отримують комунальні субсидії замість того, щоб повернути їм переплачений ПДФО на собівартість утримання кожного члена родини, не забираючи цей платіж через чиновницьку систему та управління соціального захисту населення. Такі нововведення, крім того, стимулюватимуть українців не приховувати доходи, тому що вони знатимуть, що їм за підсумками податкового року буде повернута частина сплаченого ними ПДФО.

Висновки. Вважаємо дану ресрорму щодо оподаткування не працюючої людини, а відразу цілого домогосподарства, правильною, про що свідчить досвід розвинутих країн світу. Існуюча сьогодні в нашій державі система породжує дискримінацію, оскільки, для прикладу, працюючий громадянин, в родині якого $є$ інваліди або неповнолітні діти, фрактично перебирає «на свої плечі» частину фоункцій, які має здійснювати держава щодо їх утримання, але сплачує податків стільки ж, скільки і інший громадянин, який не змушений нікого утримувати, саме по цій причині забирати податки у такої категорії працюючих громадян кардинально неправильно.

Однак перш ніж запроваджувати дану ресрорму на практиці, необхідно здійснити ряд змін, а саме:

1) порахувати коректно реальний на даний момент розмір прожиткового мінімуму, який однозначно більший, ніж той, що встановлений сьогодні. На нашу думку він приблизно становить 5-6 тисяч гривень на місяць.

2) необхідно буде домогтися поступового збільшення добробуту населення до рівня реального прожиткового мінімуму із розрахунку на кожного члена родини. Без цього кроку забезпечити повернення податку на доходи фрізичних осіб з бюджету не буде можливим, оскільки просто не буде на це коштів.

3) обчислити відсоток ставок оподаткування таким чином, щоб після сплати податків дохід на кожного члена родини не став нижчим за прожитковий мінімум. 


\section{СПИСОК ВИКОРИСТАНИХ ДЖЕРЕЛ:}

1. Десятнюк О.М. Інновації податку на доходи фізичних осіб у контексті норм Податкового кодексу України. Актуальні проблеми розвитку економіки регіону. 2012. Вип. VIII. Ч. 2. С. 3-9.

2. Круковська О.В. Ключові зміни в ресрормуванні податкової системи України: реалії та перспективи. Мукачівський державний університет. 2016. № 2. С. 702-709.

3. Легкоступ І.І., Кацуба К.В. Податкові системи в умовах глобалізації: проблеми взаємодії та перспективи розвитку. Бізнес-Інфоорм. 2014. № 14. С. 259-263.

4. Мельник В.М. Фискальная эфффективность налога с доходов фиизических лиц в Украине: возможности роста. Финансы Украины. 2007. № 12. С. 38-41.

5. Мельник І.Б. Зарубіжний досвід щодо оподаткування доходів фрізичних осіб: URL: http://intkonf.org/ melnik-ib-zarubizhniy-dosvid-schodo-opodatkuvannyadohodiv-fizichnih-osib

6. Найденко О.Є. Вплив регулятивного потенціалу податку на доходи фрізичних осіб на соціальний захист населення. Економічні науки : науковий вісник Херсонського державного університету. 2016. Випуск 16. № 2. C. 121-125.

7. Непочатенко О.О., Боровик П.М., Парій Д.Ю. Оновлений механізм справляння податку на доходи фізичних осіб: проблеми та перспективи. Економіка. Управління. Інновації. Серія : Економічні науки. 2016. № 1. URL: http://nbuv.gov.ua/UJRN/eui_2016_1_16

8. Носова Є.А. Тіньова заробітна плата в Україні: причини існування та шляхи подолання. Соціально-трудові відносини: теорія та практика. 2013. № 2. С. 110-115.

9. Податковий кодекс України : Закон України від 02.12.2010 р. № 2755 URL: https://zakon.rada.gov.ua/laws/ main/2755-17

10. Про внесення змін до Податкового кодексу України та деякі закони України (щодо податкової реформи) : Закон України від 16.05.2019 р. № 2725-VIII. URL: https://zakon.rada.gov.ua/laws/main/2628-19

11. Соколовська А.М. Фіскальна політика в Україні та ії макроекономічні наслідки. Фінанси України. 2014. № 11. С. 17-32.

12. Танклевська Н.С. Світовий досвід оподаткування доходів фізичних осіб. Наукові праці Полтавської державної аграрної академії. Економічні науки. 2013. Т. 1. Вип. 1(6). С. 264-268.

13. Толочко В.М., Музика Т.Ф. Огляд механізму стягування податків в Україні та деяких країнах світу. Современная фрармация. 2016. С. 71-74.

14. Швабій К.І. Регулятивна ефективність податку на доходи фізичних осіб в Україні. Фінанси України. 2013. № 4. C. $27-44$.

15. Швець Ю.О., Бахметова Я.Ю. Оподаткування доходів фрізичних осіб: проблеми та перспективи в Україні та ЄС. Глобальні та національні проблеми економіки. 2017. № 17. С. 771-775.

16. Юрчишина Л.В. Податок на доходи фрізичних осіб: механізм стягнення та джерело доходу бюджету України. Фінанси, облік, банки. 2016. Вип. 1. С. 215-224.

\section{REFERENCES:}

1. Desiatniuk O. M. (2012) Innovatsii podatku na dokhody fizychnykh osib u konteksti norm Podatkovoho kodeksu Ukrainy [Innovations of the personal income tax in the context of the provisions of the Tax Code of Ukraine]. Aktualni problemy rozvytku ekonomiky rehionu [Actual problems of economic development of the region], vol. 2, VIII, pp. 3-9. (in Ukrainian)

2. Krukovska O. V. (2016) Kliuchovi zminy v reformuvanni podatkovoi systemy Ukrainy: realii ta perspektyvy [Key changes in tax reform of Ukraine: realities and prospects]. Muchakivskyi derzhavnyi universytet [Muchakiv State University], no. 2, pp. 702-709. (in Ukrainian)

3. Lehkostup I. I., Katsuba K. V. (2014) Podatkovi systemy v umovakh hlobalizatsii: problemy vzaiemodii ta perspektyvy rozvytku [Tax systems in the conditions of globalization: problems of interaction and prospects of development]. Biznes-Inform [Business Inform], no. 14, pp. 259-263. (in Ukrainian)

4. Melnyk V. M. (2007) Fyskalnaia effektyvnost naloha s dokhodov fyzycheskykh lyts v Ukrayne: vozmozhnosty rosta [Fiscal Efficiency of the Personal Income Tax in Ukraine: Opportunities for Growth]. Fynansy Ukrayny [Finance of Ukraine], no. 12, pp. 38-41. (in Ukrainian)

5. Melnyk I. B. Zarubizhnyi dosvid shchodo opodatkuvannia dokhodiv fizychnykh osib [Foreign experience in taxation of individual incomes]. Available at: http://intkonf.org/melnik-ib-zarubizhniy-dosvid-schodo-opodatkuvannya-dohodiv-fizichnih-osib (accessed 31 May 2021). (in Ukrainian)

6. Naidenko O. Ye. (2016) Vplyv rehuliatyvnoho potentsialu podatku na dokhody fizychnykh osib na sotsialnyi zakhyst naselennia [Influence of the Regulatory Potential of the Personal Income Tax on the Social Protection of the 
Population]. Ekonomichni nauky: naukovyi visnyk Khersonskoho derzhavnoho universytetu [Economic Sciences: Scientific Bulletin of the Kherson State University], vol. 16, no. 2, pp. 121-125. (in Ukrainian)

7. Nepochatenko O. O., Borovyk P. M., Parii D. Yu. (2016) Onovlenyi mekhanizm spravliannia podatku na dokhody fizychnykh osib: problemy ta perspektyvy [The updated mechanism of taxation on personal income: problems and prospects]. Ekonomika. Upravlinnia. Innovatsii. Seriia: Ekonomichni nauky [Economics. Management. Innovation], no. 1. Available at: http://nbuv.gov.ua/ UJRN/eui_2016_1_16 (accessed 30 May 2021). (in Ukrainian)

8. Nosova Ye.A. (2013)TinovazarobitnaplatavUkraini: prychynyisnuvanniatashliakhypodolannia[Shadowwages in Ukraine: reasons for existence and ways to overcome it]. Sotsialno-trudovi vidnosyny: teoriia ta praktyka [Sociallabor relations: theory and practice], no. 2, pp. 110-115. (in Ukrainian)

9. Podatkovyi kodeks Ukrainy: Zakon Ukrainy vid 02.12.2010 r. no. 2755 [Tax code of Ukraine: Law of Ukraine from 02.12.2010 No. 2755]. Available at: https://zakon.rada.gov.ua/laws/main/2755-17 (in Ukrainian)

10. Pro vnesennia zmin do Podatkovoho kodeksu Ukrainy ta deiaki zakony Ukrainy(shchodo podatkovoi reformy) [On Amendments to the Tax Code of Ukraine and Some Laws of Ukraine (regarding tax reform)]: Law of Ukraine from 16.05.2019 No. 2725-VIII. Available at: https://zakon.rada.gov.ua/laws/main/2628-19 (in Ukrainian)

11. Sokolovska A. M. (2014) Fiskalna polityka v Ukraini ta yii makroekonomichni naslidky [Fiscal policy in Ukraine and its macroeconomic consequences]. Finansy Ukrainy [Finance of Ukraine], no. 11, pp. 17-32. (in Ukrainian)

12. Tanklevska N. S. (2013) Svitovyi dosvid opodatkuvannia dokhodiv fizychnykh osib [World experience of taxation of personal income]. Naukovi pratsi Poltavskoi derzhavnoi ahrarnoi akademii. Ekonomichni nauky [Scientific works of Poltava State Agrarian Academy. Economic sciences], no. 1(6), pp. 264-268. (in Ukrainian)

13. Tolochko V. M., Muzyka T. F. (2016) Ohliad mekhanizmu stiahuvannia podatkiv v Ukraini ta deiakykh krainakh svitu [Overview of the tax collection mechanism in Ukraine and some countries in the world]. Sovremennaia farmatsyia [Modern pharmacy], pp. 71-74. (in Ukrainian)

14. Shvabii K. I. (2013) Rehuliatyvna efektyvnist podatku na dokhody fizychnykh osib v Ukraini [Regulatory Effectiveness of the Personal Income Tax in Ukraine]. Finansy Ukrainy [Finance of Ukraine], no. 4, pp. 27-44. (in Ukrainian)

15. Shvets Yu. O., Bakhmetova Ya. Yu. (2017) Opodatkuvannia dokhodiv fizychnykh osib: problemy ta perspektyvy v Ukraini ta YeS [Personal Income Taxation: Problems and Prospects in Ukraine and the EU]. Hlobalni ta natsionalni problemy ekonomiky [Global and national problems of economy]//Mykolaivskyi natsionalnyi universytet imeni V.O. Sukhomlynskoho [Mykolaiv National University of V.O. Sukhomlinskyi], no. 17, pp. 771-775. (in Ukrainian)

16. Yurchyshyna L. V. (2016) Podatok na dokhody fizychnykh osib: mekhanizm stiahnennia ta dzherelo dokhodu biudzhetu Ukrainy [Personal income tax: mechanism of collection and source of income of the budget of Ukraine]. Finansy, oblik, banky [Finance, accounting, banks], no. 1, pp. 215-224. (in Ukrainian) 